\title{
Kainate Receptors Mediate Signaling in Both Transient and Sustained OFF Bipolar Cell Pathways in Mouse Retina
}

\author{
Bart G. Borghuis, ${ }^{1,4}$ Loren L. Looger, ${ }^{5}$ Susumu Tomita, ${ }^{2,3}$ and Jonathan B. Demb ${ }^{1,2}$ \\ ${ }^{1}$ Department of Ophthalmology and Visual Science, ${ }^{2}$ Department of Cellular and Molecular Physiology, and ${ }^{3}$ Program in Cellular Neuroscience, \\ Neurodegeneration and Repair, Yale University School of Medicine, New Haven, Connecticut 06511, ${ }^{4}$ Department of Anatomical Sciences and \\ Neurobiology, University of Louisville, School of Medicine, Louisville, Kentucky 40202, and ${ }^{5}$ Howard Hughes Medical Institute, Janelia Farm Research \\ Campus, Ashburn, Virginia 20147
}

\begin{abstract}
A fundamental question in sensory neuroscience is how parallel processing is implemented at the level of molecular and circuit mechanisms. In the retina, it has been proposed that distinct OFF cone bipolar cell types generate fast/transient and slow/sustained pathways by the differential expression of AMPA- and kainate-type glutamate receptors, respectively. However, the functional significance of these receptors in the intact circuit during light stimulation remains unclear. Here, we measured glutamate release from mouse bipolar cells by two-photon imaging of a glutamate sensor (iGluSnFR) expressed on postsynaptic amacrine and ganglion cell dendrites. In both transient and sustained OFF layers, cone-driven glutamate release from bipolar cells was blocked by antagonists to kainate receptors but not AMPA receptors. Electrophysiological recordings from bipolar and ganglion cells confirmed the essential role of kainate receptors for signaling in both transient and sustained OFF pathways. Kainate receptors mediated responses to contrast modulation up to $20 \mathrm{~Hz}$. Light-evoked responses in all mouse OFF bipolar pathways depend on kainate, not AMPA, receptors.
\end{abstract}

Key words: glutamate sensor; kainate receptor; mouse; OFF bipolar cell; retinal circuitry; two-photon imaging

\section{Introduction}

A fundamental property of all sensory systems is the simultaneous encoding of the environment by multiple cellular pathways. In the visual system, parallel processing starts at the first synapse in the retina (Wässle, 2004; Masland, 2012; Sterling, 2013). Parallel processing is especially evident at the output of cone photoreceptors, which mediate daylight vision (Fig. 1A). Each cone releases glutamate onto approximately a dozen types of cone bipolar cell that divide into ON and OFF classes (Haverkamp and Wässle, 2000; Wässle et al., 2009). Cones hyperpolarize to light increments, and depolarize to light decrements. OFF bipolar cells express non-NMDA-type ionotropic glutamate receptors (iGluRs: AMPA/kainate receptors) and thereby follow the sign of the cone's response (i.e., depolarize to light decrements; DeVries, 2000), whereas ON bipolar cells express metabotropic glutamate receptor type 6 (mGluR6) and thereby invert the sign of the cone's response (i.e., depolarize to light increments; Slaughter and Miller, 1981; Nakajima et al., 1993; Morgans et al., 2009; Shen

\footnotetext{
Received Nov. 25, 2013; revised Feb. 6, 2014; accepted March 7, 2014

Author contributions: B.G.B., S.T., and J.B.D. designed research; B.G.B. performed research; L.L.L. contributed unpublished reagents/analytic tools; B.G.B. analyzed data; B.G.B., L.L.L., S.T., and J.B.D. wrote the paper.

This research was funded by NIH/NEI Grants R01 EY014454 (J.B.D.) and R21 EY023038 (B.G.B., J.B.D.), NIH/NIMH Grant R01 MH085080 (S.T.), the Howard Hughes Medical Institute (L.L.L.), and an unrestricted grant from Research to Prevent Blindness to Yale University.

Conflict of interest: B.G.B. owns Borghuis Instruments, which sells the specialized syringe that was used for intravitreal virus injections in this study.

Correspondence should be addressed to either of the following: Dr. Jonathan Demb, Yale University School of Medicine, 300 George Street, Suite 8100, New Haven, CT 06511, E-mail: jonathan.demb@yale.edu or Dr. Bart Borghuis, Department of Anatomical Sciences and Neurobiology, University of Louisville School of Medicine, 511 S. Floyd Street, MDR 425A, Louisville, KY 40202, E-mail: bart.borghuis@louisville.edu.

DOI:10.1523/JNEUROSCI.4941-13.2014

Copyright $\odot 2014$ the authors $\quad 0270-6474 / 14 / 346128-12 \$ 15.00 / 0$
}

et al., 2009). ON and OFF classes each comprise 5-6 distinct types that mediate additional levels of parallel processing along spatial, temporal, and chromatic dimensions (Cohen and Sterling, 1990; Kouyama and Marshak, 1992; Li and DeVries, 2006; Wässle et al., 2009; Breuninger et al., 2011; Baden et al., 2013).

The mechanism for distinct temporal responses in parallel pathways, fast/transient versus slow/sustained, is unresolved. All ON bipolar cell types express mGluR6 receptors (Vardi et al., 2000), so distinct temporal responses must depend on cell typespecific differences in intrinsic (Awatramani and Slaughter, 2001; Ivanova et al., 2006; Cui et al., 2012; Saszik and DeVries, 2012) or circuit properties (e.g., inhibitory feedback; Eggers and Lukasiewicz, 2011). For OFF bipolar cells, it has been hypothesized that transient and sustained pathways may be generated instead by cell-type-dependent expression of specific glutamate receptors. Transient cells would express AMPA-type receptors (AMPARs), with relatively fast recovery from desensitization, and sustained cells would express kainate-type receptors (KARs) either exclusively or predominantly, with relatively slow recovery from desensitization (DeVries, 2000; Lindstrom et al., 2014). The evidence for this hypothesis derives primarily from paired cone $\rightarrow$ OFF bipolar cell recordings in slice preparations of ground squirrel retina (DeVries, 2000; DeVries et al., 2006; Li et al., 2010; Lindstrom et al., 2014). Physiological experiments in other species do not clearly support this model: iGluR agonist application in mouse retinal slices, and light-evoked stimulation in rabbit retinal slices suggested that some OFF bipolar cell types express a mixture of AMPARs and KARs (Buldyrev et al., 2012; Puller et al., 2013). Neither study indicates a major role for AMPARs in encoding light-evoked synaptic release in OFF bipolar cells. 
A

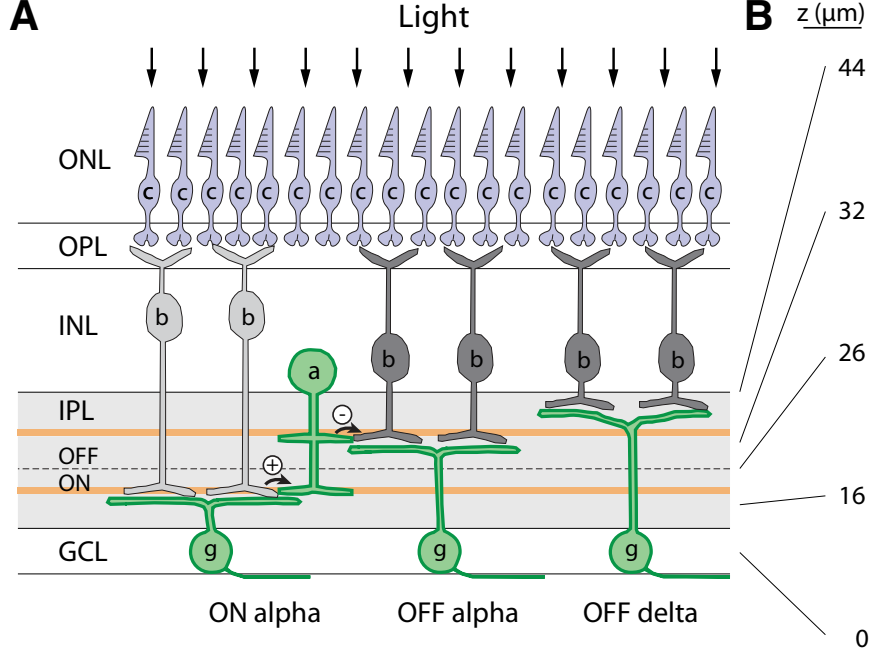

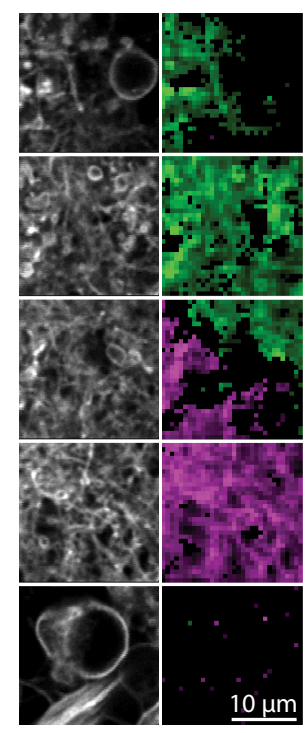

C stimulus

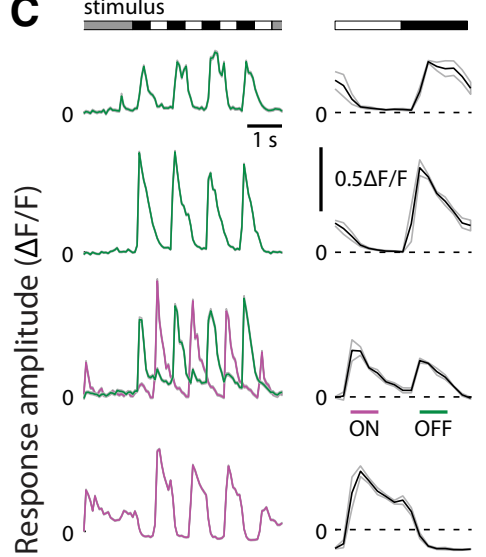

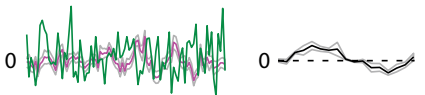

D

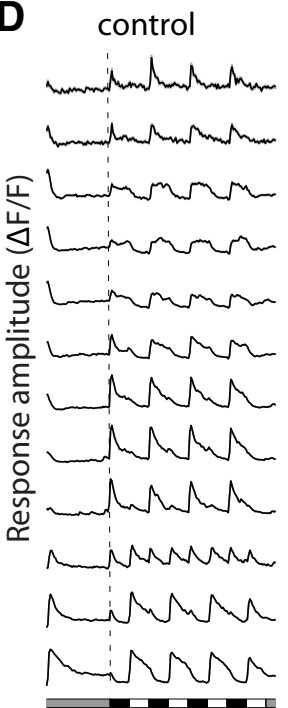

DNQX

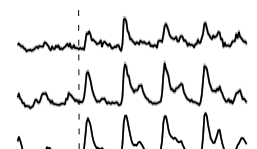

h ham winghr minph induh

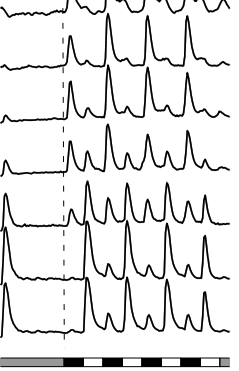

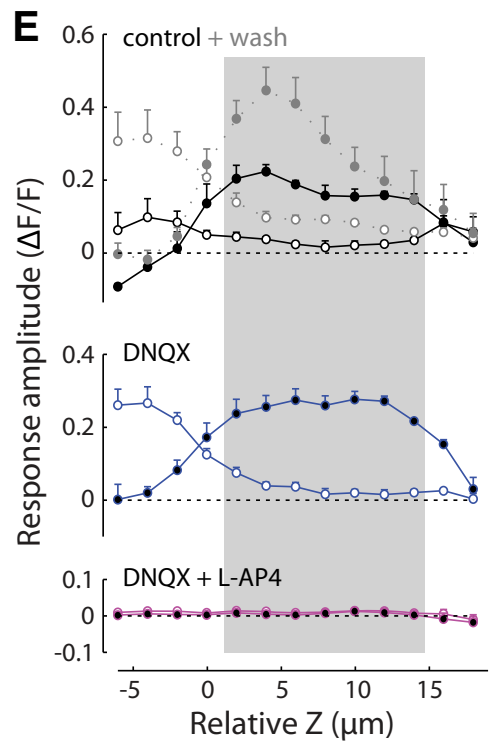

Figure 1. ON-pathway crossover inhibition drives glutamate release in all OFF-levels of the IPL.A, UV light stimuli were projected onto the photoreceptors (cones, c; rods were saturated and are omitted from schematic for clarity). Light-evoked glutamate release from ON-type (light gray) and OFF-type (dark gray) bipolar cells (b) was measured with two-photon fluorescence imaging of iGluSnFR (green), expressed on the dendriticarbors of ganglion ( $\mathrm{g}$ ) and amacrine cells (a). A crossover inhibition pathway is shown: ON bipolar cell excites $(+)$ amacrinecell, which inhibits ( - ) OFFbipolar cell terminals. Orange linesillustrate the stratification depths of ON-and OFF-type starburst amacrine cells, a commonly used anatomical marker in the retina. Dashed line indicates the ON/OFF boundary (see B) B, Left, Fluorescence image of labeled processes at the indicated focal planes. Right, Light-evoked responses were $0 \mathrm{~N}$-type (increase to light, magenta) from the ganglion cell layer to the central IPL and OFF-type (decrease to light, green) from the central IPL to the innernuclear layer, with mixed, spatially nonoverlapping regions atthe ON/OFF junction $(z=26 \mu \mathrm{m})$. C, Left, Fluorescence responses ofON and OFF regions shown in $B$. Right, Average response of all pixels with significant modulation (see Materials and Methods). Responses to three periods were averaged (shaded area: mean \pm SEM). ON- and OFF-response at each level were defined as the amplitude of the fluorescence signal in $200 \mathrm{~ms}$ windows (indicated with magenta and green lines) relative to baseline. D, Average fluorescence response at 12 levels of the IPL, centered on the 0FF layers (control; left). All OFF-type responses persisted in the presence of the iGluR antagonist DNQX (100 $\mu$; ; center). Additional block of the ON-pathway (L-AP4, $20 \mu \mathrm{M}$ ) eliminated all responses (data from a single retinal location). E, Average ON (open symbols) and OFF (closed symbols) response amplitudes in control, DNQX and DNQX + L-AP4 ( $n=6$ locations, three retinas). Response after wash is shown with control (top). The ON/OFF junction was located $\sim 25-30 \mu \mathrm{m}$ distal to the ganglion cell layer (see Materials and Methods). In this panel and in subsequent figures z-positions are expressed relative to the 0N/OFF junction (relative Z). $\boldsymbol{F}$, Schematic of the drug perturbations. L-AP4 blocks synaptic input to ON bipolar cells (light gray); DNQX blocks synaptic input to OFF bipolar cells (dark gray). DNQX additionally blocks glutamatergic input to amacrine and ganglion cells (notillustrated). G, Bargraph of response amplitudes averaged across the principal OFFlevels (14 $\mu \mathrm{mZ}$-range, indicated by shaded region in E) in the presence of DNQX + L-AP4 (left; $\mathrm{n}=6$ locations, three retinas) and DNQX $+1 \mu \mathrm{m}$ strychnine (right; $n=4$ locations, two retinas); ${ }^{*} p<0.01$.

Here, we tested the roles of AMPARs and KARs in OFF bipolar pathways using two-photon fluorescence imaging of a glutamate biosensor and whole-cell recording in the intact mouse retina in vitro. Our results show that light-evoked responses of all OFF bipolar cell types, both transient and sustained, critically depend on KARs but not AMPARs, and that KARs are sufficiently fast to signal light-evoked release modulated up to $20 \mathrm{~Hz}$.

\section{Materials and Methods}

The procedures for retinal preparation, patch-clamp recording and two-photon imaging of iGluSnFR fluorescence were identical to those described previously (Borghuis et al., 2013). All procedures were conducted in accordance with National Institutes of Health guidelines under protocols approved by the Yale University or University of Louisville Animal Care and Use Committees. The eyes of C57/B6 mice of either sex (2-6 
months of age) were removed immediately following death. Each retina was dissected in carbogenated $\left(95 \% \mathrm{O}_{2}-5 \% \mathrm{CO}_{2}\right)$ Ames Medium (SigmaAldrich) using a microscope equipped with infrared viewers, as described previously (Borghuis et al., 2013). The retina was then transferred to a chamber on the stage of an Olympus microscope and perfused with heated, carbogenated Ames medium $\left(\sim 6 \mathrm{ml} / \mathrm{min} ; 34-36^{\circ} \mathrm{C}\right)$. The receptor agonists, antagonists and transporter blockers (purchased from Tocris Bioscience), described below, were added to Ames medium from drug reservoirs. The KAR selective antagonists ACET $(1 \mu \mathrm{M})$ and UBP310 (50 $\mu \mathrm{M})$ showed similar effects in our experiments. They were used interchangeably, and data obtained with either drug are combined in Figure $3 B, D$.

Light stimuli were designed to stimulate cones. The majority of mouse cones coexpress two opsins with a gradient of coexpression along the dorsal-ventral axis (Röhlich et al., 1994; Applebury et al., 2000). Cones in the dorsal retina express primarily a middle-wavelength (M)-sensitive opsin with peak sensitivity to green light $(510 \mathrm{~nm})$, whereas cones in the ventral retina express almost exclusively a short-wavelength (S)-sensitive opsin with peak sensitivity to UV light (Nikonov et al., 2006; Wang et al., 2011; Baden et al., 2013; $365 \mathrm{~nm}$ ). All measurements were made in the ventral retina, except for the data presented in Figure 3D. Light stimuli delivered from a customized projector (peak output, $395 \mathrm{~nm}$ ) through the condenser activated $\sim 10^{4}$ photoisomerizations $\left(R^{\star}\right)$ cone $^{-1} \mathrm{sec}^{-1}$; rods are largely suppressed at this light level and in the presence of the laser used for two-photon imaging, as described previously (Borghuis et al., 2013). The standard stimulus was a disk (0.4-mm diameter) centered on a background at mean luminance $(4 \times 3 \mathrm{~mm}$ on the retina). Luminance of the disk was modulated with a $1 \mathrm{~Hz}$ temporal square-wave at $100 \%$ Michelson contrast. For the electrophysiological measurements presented in Figure 3E, two stimulus conditions were used in addition to the standard stimulus: in the first, the mean light level was reduced by 2 log-units using a neutral density filter; in the second the disk was presented on a dark background, to maximize contrast (effective contrast ratio of 1000:1). For the temporal tuning measurements presented in Figure $6, A$ and $B$, the stimulus was a $0.3 \times 0.3-\mathrm{mm}$ square generated with a software-controlled light-emitting diode (peak output, $405 \mathrm{~nm}$ ) at $100 \%$ contrast (same mean $R^{\star}$ rate as the projector).

Two-photon fluorescence measurements were obtained with a custom built microscope controlled with ScanImage software (www.scanimage. org; Pologruto et al., 2003), using an Olympus 60×, 1.0 NA, LUMPlanFl/IR objective and an ultrafast pulsed laser (Chameleon Ultra II, Coherent) tuned to $910 \mathrm{~nm}$, as described previously (Borghuis et al., 2013). Whole-cell recordings were made from ganglion and bipolar cells in the whole-mount retina using the following intracellular solution (in $\mathrm{mm}$ ): 100 Cs-methanesulfonate, 5 TEA-Cl, 10 HEPES, 10 BAPTA, 3 $\mathrm{NaCl}, 2$ QX-314-Cl, 4 ATP-Mg, 0.4 GTP-Na $\mathrm{N}_{2}$, and 10 phosphocreatine$\mathrm{Tris}_{2}$, pH 7.3 (280 mOsm). Excitatory currents were recorded with a holding potential near $\mathrm{E}_{\mathrm{Cl}}(-67 \mathrm{mV})$ after correcting for the liquid junction potential $(-9 \mathrm{mV})$.

Stimulus-evoked fluorescence responses (32 frames/s) were acquired in $z$-stacks that encompassed the entire OFF half of the inner plexiform layer (IPL). The $z=0 \mu \mathrm{m}$ level was defined as the focal plane that hemisected the ganglion cell somas. Stacks were acquired from the vitreal side of the ON/OFF boundary (typical $z=20 \mu \mathrm{m}$ ) to the inner nuclear layer (i.e., focal plane that intersected the first layer of cell bodies; typical $z=48 \mu \mathrm{m})$. The light stimulus consisted of $1.5 \mathrm{~s}$ of a gray screen followed by $3.5 \mathrm{~s}$ of contrast modulation of a $0.4-\mathrm{mm}$-diameter disk ( $1 \mathrm{~Hz}$ square wave). The stimulus was repeated three times with a $3 \mathrm{~s}$ interstimulus interval; after the third repeat, the focus was automatically advanced 2 $\mu \mathrm{m}$ toward the inner nuclear layer, and the stimulus sequence was repeated. Obtaining a complete $z$-stack between the middle of the IPL and the inner nuclear layer required $\sim 7 \mathrm{~min}$.

Images $(20 \times 20 \mu \mathrm{m})$ were down-sampled in software to $32 \times 32$ pixels $(0.63 \times 0.63 \mu \mathrm{m}$ per pixel), using boxcar averaging. Pixels whose fluorescence intensity during the respective stimulus on- and off-phase (300 ms window) exceeded one SD above the average intensity just before stimulus onset (500 ms window) were defined as significantly modulating $\mathrm{ON}$ - and OFF-responding pixels, respectively (Fig. $1 B, C$ ). These pixels were grouped into separate $\mathrm{ON}$ and OFF ROIs. Where ON and OFF responses are not presented separately, the average of all signifi- cantly modulating pixels is shown (Fig. 1C). Population data shown in Figure $6 E$ were based on a total of 30 line scans for each condition. Using a computer algorithm, each line scan ( $25 \mu \mathrm{m}$ length) was divided into 10 equal-sized ROIs. ROIs were sorted based on the modulation amplitude of their response to $1 \mathrm{~Hz}$ stimulation. The two most strongly modulating ROIs from each line scan were selected and the modulation amplitude of their response to $7.5 \mathrm{~Hz}$ was combined, culminating in data for $60 \mathrm{ROIs}$ in each condition in Figure $6 E$.

All data are reported as mean \pm SEM. The effects of drug applications were evaluated by two-tailed repeated measures $t$ tests.

\section{Results}

\section{Glutamate imaging in the intact mouse retina}

We monitored light-evoked synaptic release of OFF-type bipolar cells during selective perturbations of AMPARs and KARs. Synaptic release from bipolar cells was measured using two-photon fluorescence imaging of the glutamate biosensor intensity-based glutamate-sensing fluorescent reporter (iGluSnFR; Borghuis et al., 2013; Marvin et al., 2013) expressed on the dendrites of their postsynaptic targets, the ganglion and amacrine cells (Fig. 1A).

iGluSnFR was delivered by in vivo intraocular injection with adeno-associated virus under control of the human synapsin-1 promoter (AAV2/1-hSynapsin-iGluSnFR), as described previously (Borghuis et al., 2013). Retinas were recorded 2-3 weeks after injection. Cones were stimulated with patterned UV light $\left(\lambda_{\max }=395 \mathrm{~nm}\right)$ projected through the microscope's condenser (Borghuis et al., 2013) while fluorescence responses were recorded at multiple levels of the IPL, including all levels where OFF bipolar terminals stratify (Fig. $1 A, B)$. At each level, $\mathrm{ON}$ - and OFF-responding pixels were detected, based on a threshold and the response sign, and grouped into $\mathrm{ON}$ - and OFF-responding regions accordingly (see Materials and Methods; Fig. $1 B, C$ ).

The iGluSnFR signals reflected the basic organization of the IPL. ON responses localized to the proximal half of the IPL, nearest to the ganglion cell layer and OFF responses localized to the distal half, nearest to the inner nuclear layer (INL; Fig. $1 B, D$ ). In an intermediate layer, both $\mathrm{ON}$ and $\mathrm{OFF}$ signals occurred simultaneously in spatially nonoverlapping regions (Fig. 1 B, C; Borghuis et al., 2013). OFF layers included both transient and sustained responses (Fig. 1C,D), with transient signals nearest the center of the IPL, and sustained signals nearest the INL. Some stacks showed additional transient responses at the INL border (Fig. 1D).

\section{Kainate receptors mediate both transient and sustained OFF bipolar pathways}

Two distinct pathways mediate glutamate release from OFF bipolar terminals following light decrements. First, cones release glutamate onto iGluRs (AMPAs or KARs) expressed on the bipolar cell dendrites, causing depolarization. Second, crossover ON amacrine cells relieve their tonic inhibition of the OFF bipolar terminal, also causing depolarization. Hence the cones and crossover amacrine pathways form a push-pull circuit with the same influence on OFF bipolar terminals (Fig. $1 A, F$ ): light decrement evokes glutamate release (Werblin, 2010). To study the specific contribution of the cone $\rightarrow$ OFF bipolar cell synapse, we first designed experiments to distinguish this contribution from the crossover amacrine cell pathways.

Cone input to OFF bipolar dendrites was blocked by bathapplication of the AMPAR/KAR antagonist DNQX (100 $\mu \mathrm{M})$. In the presence of DNQX, iGluSnFR responses persisted in all OFF layers of the IPL and were significantly increased $(n=4 ; 0.10 \pm$ 0.01 vs. $0.17 \pm 0.01,63.9 \pm 12.3 \%$ increase, $t=4.12, p=0.0062$; 


\section{A} control

L-AP4

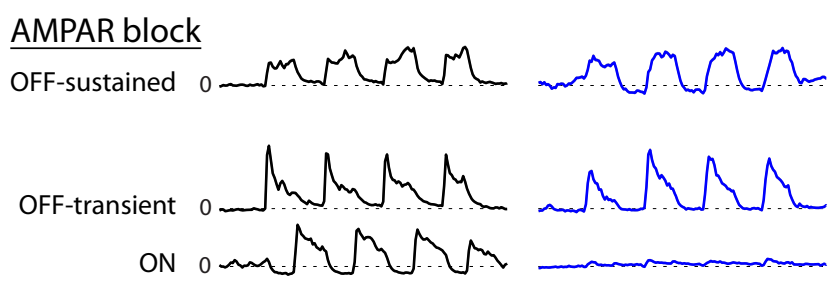

L-AP4
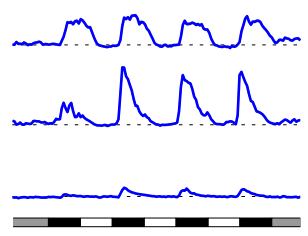

L-AP4 + GYKI52466
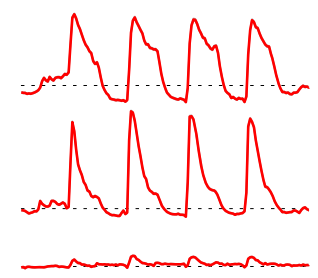

L-AP4 + ACET
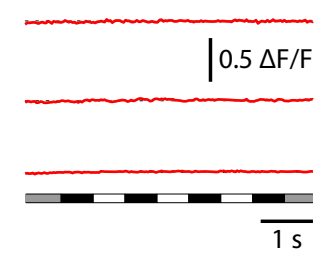

B
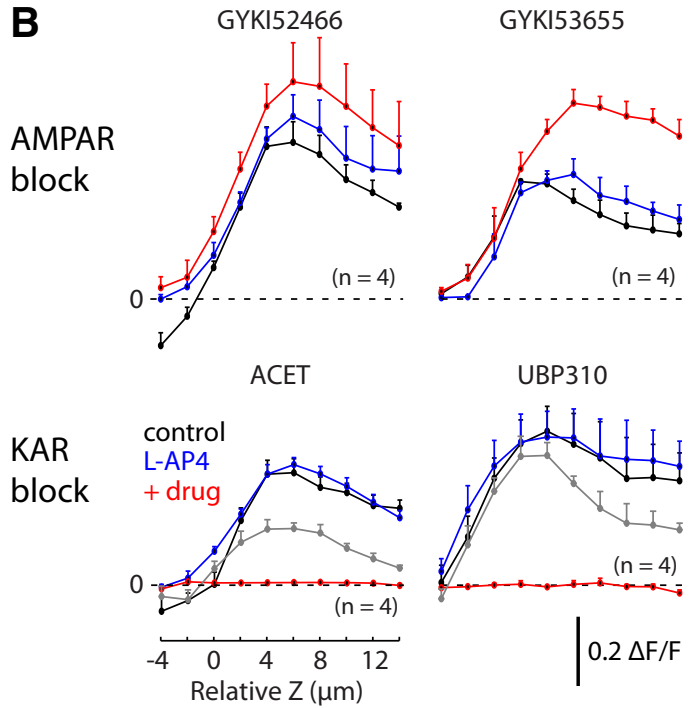

ACET

GYKI53655

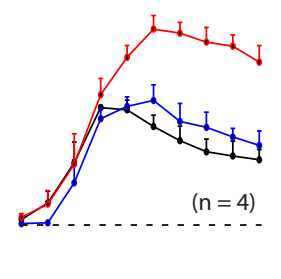

UBP310
C
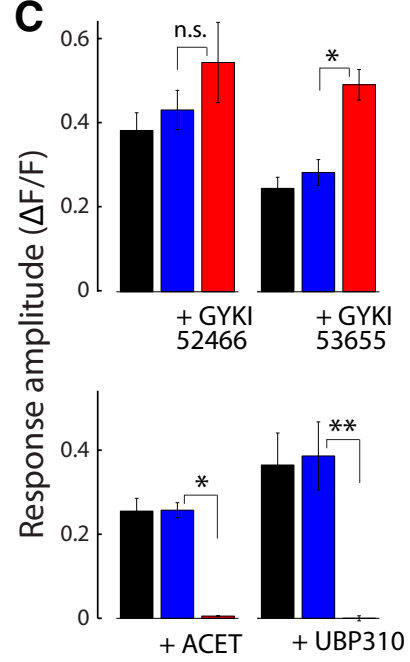

Figure 2. Kainate receptor antagonists block synaptic release from all OFF-type bipolar cells. $\boldsymbol{A}$, Fluorescence responses in an $0 \mathrm{~N}$ (relative $Z=-4$ ), transient OFF (relative $Z=6$ ) and sustained OFF layer (relative $Z=12$ ) of the IPL. $\boldsymbol{B}$, Fluorescence responses at OFF-levels of the IPL in the presence of iGluR blockers: AMPAR antagonists GYKI52466 $(100 \mu \mathrm{M})$ and GYKI53655 (100 $\mu \mathrm{M})$; KAR antagonists ACET $(1 \mu \mathrm{M})$ and UBP310 (50 $\mu \mathrm{M})$. Gray curves (bottom) show the response after 15 min wash to control condition. $Z$ is defined relative to the $0 N / 0 F F$ boundary. $C$, Bar graph of response amplitudes for each condition shown in $\boldsymbol{B}$. Responses were averaged across eight z-planes, spanning $14 \mu \mathrm{m}$ (Fig. 1E). n.s., Not significant; ${ }^{*} p<$ $0.005 ;{ }^{* *} p=0.020$.

Fig. $1 D-G)$. Because DNQX has broad actions in the retina, its effect was difficult to predict; DNQX blocks inputs to horizontal cells in the outer retina as well as multiple amacrine cells in the inner retina, including cells that either inhibit or disinhibit OFF bipolar terminals. The net effect of DNQX was an increase in OFF bipolar release, suggesting its dominant action was to block the inhibitory cells that initially suppressed OFF bipolar terminals (Eggers and Lukasiewicz, 2011; Sagdullaev et al., 2011).

In the presence of DNQX, near the ON-OFF boundary additional OFF responses became detectable in ON layers and additional ON responses became detectable in OFF layers (Fig. 1D). This spread of ON and OFF signals can be explained by voxel averaging of increased release in synaptic layers immediately above and below the focal plane, given the point-spread function of our optical system (full-width at half-maximum, $2.35 \mu \mathrm{m}$; Borghuis et al., 2013). Importantly, light-evoked responses in all
OFF layers remained in the presence of DNQX, including layers that were predominantly transient or sustained (Fig. $1 D)$. We hypothesized that release from OFF bipolar terminals was mediated by the crossover inhibition from the $\mathrm{ON}$ pathway described above (Werblin, 2010). Although multiple circuits are possible, including circuits composed of serial inhibitory synapses, the simplest circuit is ON bipolar $\rightarrow$ ON amacrine $\rightarrow$ OFF bipolar (Fig. $1 F$ ).

Blocking the ON pathway with the group III mGluR agonist L-AP4 $(20 \mu \mathrm{M})$, which hyperpolarizes ON bipolar cells (Slaughter and Miller, 1981), blocked all DNQX-resistant activity (Fig. 1D-G). DNQX and L-AP4 have no direct effect on iGluSnFR (Marvin et al., 2013). Therefore, the lack of OFF responses in the presence of L-AP4 and DNQX supports a model where DNQX blocks all cone-toOFF bipolar cell transmission, and persisting release depends on ON-pathway crossover inhibition (Fig. $1 F$ ). Averaging across layers, the fluorescence response in DNQX $(0.25 \pm 0.02 ; n=4)$ was reduced by $98.0 \pm 0.4 \%$ after adding L-AP4 $(0.005 \pm 0.002 ; t=12.2, p=0.0012)$. Responses returned after washing out all drugs (Fig. 1E). To further test the mechanism underlying the crossover inhibition we selectively blocked glycine receptors. In the presence of DNQX, strychnine (1 $\mu \mathrm{M})$ suppressed, but did not eliminate, the response across OFF layers (0.38 \pm 0.04 vs $0.11 \pm 0.02 ; 70.1 \pm 18 \%$ reduction, $t=6.24, p=0.0083$ ). This shows that glycinergic amacrine cell pathways mediate the majority of crossover inhibition, but that other (presumed GABAergic) pathways contribute as well (Arman and Sampath, 2012). We conclude that relief from crossover inhibition from the ON pathway can drive synaptic release from OFF bipolar terminals at each OFF level of the IPL. Consequently, to isolate OFF bipolar responses mediated by direct cone inputs, all subsequent experiments were performed in the presence of L-AP4 (Fig. $1 F)$.

In the presence of L-AP4, iGluSnFR responses were absent in the ON layers, as expected, but responses remained in both transient and sustained OFF layers (Fig. 2A). In the presence of L-AP4, we blocked either AMPARs or KARs. Based on the prevailing model (DeVries, 2000), our hypothesis was that transient responses would be sensitive to AMPAR block, whereas sustained responses would be sensitive to KAR block. Instead, we found that OFF responses in all layers remained (and increased) in the presence of the AMPAR preferential antagonists GYKI $52466(100 \mu \mathrm{M})$ and GYKI $53655(100 \mu \mathrm{M})$; respectively, $n=4,0.43 \pm 0.05$ vs $0.55 \pm 0.10, t=0.81, p=$ 0.48 , ns; and $n=4,0.28 \pm 0.03$ vs $0.49 \pm 0.04, t=7.91, p=$ 
A ON alpha control
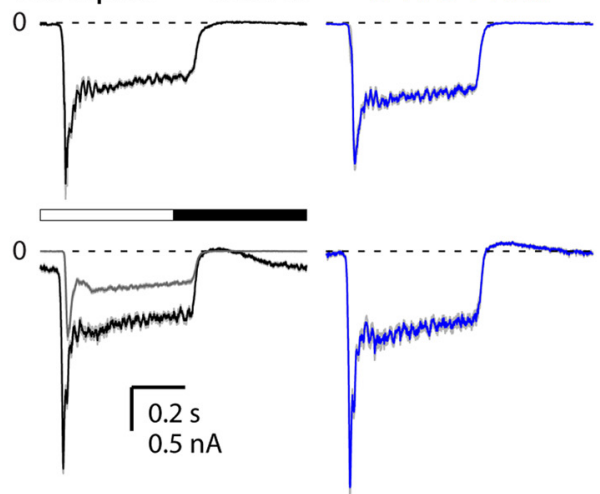

C OFF alpha

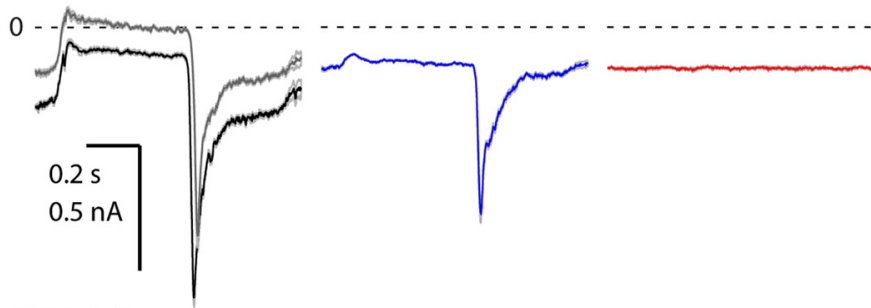

OFF delta

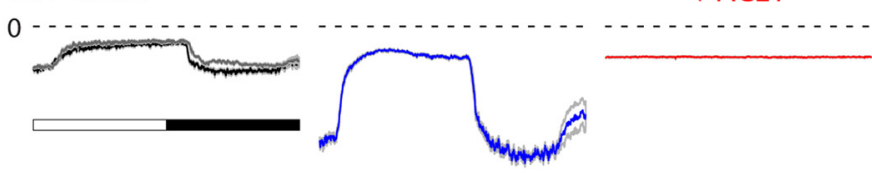

E
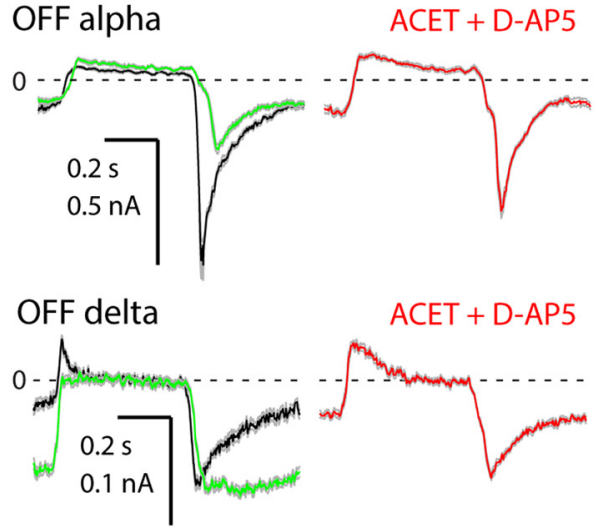

+ ACET

D-AP5 + HEX

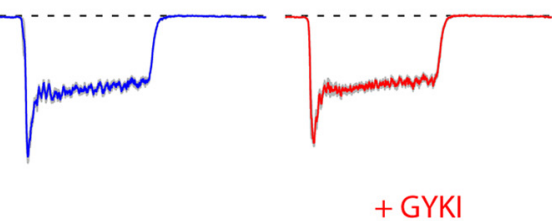

(1...............

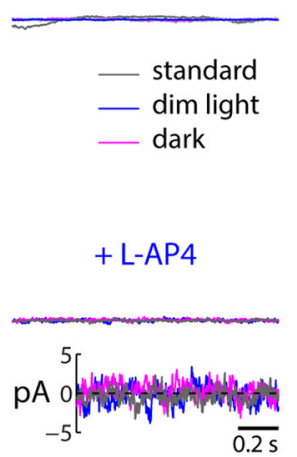

B ON alpha

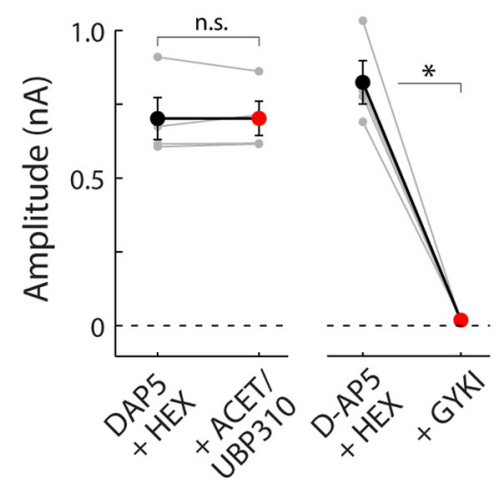

D

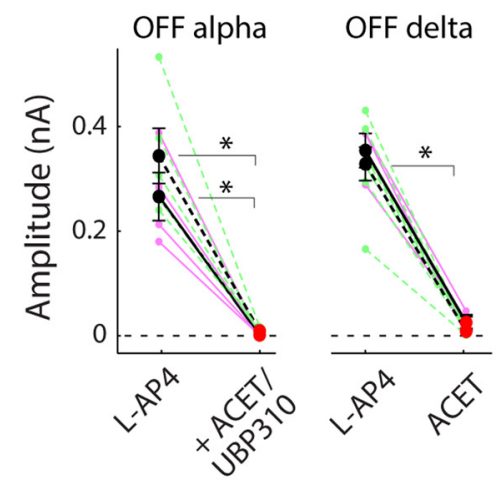

$\mathbf{F}$

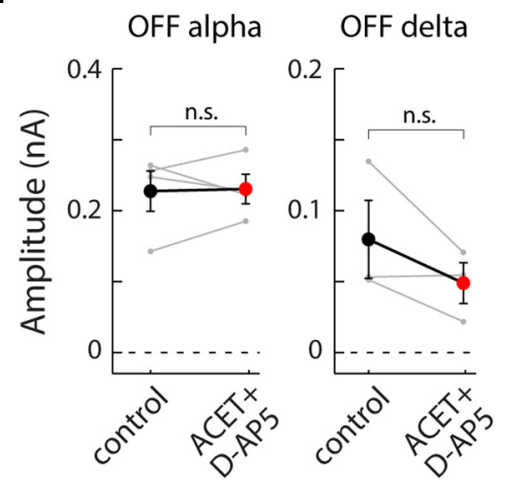

Figure 3. Kainate receptor block eliminates excitatory currents in OFF-type ganglion cells. $A$, Excitatory currents in an $0 \mathrm{~N}-\alpha$ cell (black) persisted in the presence of NMDA and ACh antagonists (D-AP5, $100 \mu \mathrm{M}$ + hexamethonium, $100 \mu \mathrm{m}$, blue) and after additional block of KARs (top;ACET $1 \mu \mathrm{M}$, red) but were blocked by antagonists of AMPARs (bottom;GYKI53655,50 $\mu \mathrm{M}$, red; GYKI53655, $100 \mu \mathrm{m}$, cyan dashed). Gray curve shows the response after 15 min wash to control condition. $\boldsymbol{B}$, Effect of KAR and AMPAR block in three 0N- $\alpha$ cells (gray, individual cells, black mean \pm SEM; amplitude was calculated over $200 \mathrm{~ms}$ window, $100 \mathrm{~ms}$ following onset of the preferred stimulus phase); ${ }^{*} p<0.01$. C, Excitatory currents in $0 \mathrm{FF}-\alpha$-and $0 \mathrm{FF}-\delta$-type ganglion cells under control conditions (black) and in the presence of L-AP4 (blue). Responses in the presence of L-AP4 were eliminated by additional block of KARs (red; UBP310, $50 \mu \mathrm{m}$ or ACET, $1 \mu \mathrm{M}$ ). Gray curves as in $A$. D, Effect of KAR block in OFF- $\alpha$ and $-\delta$ cells (individual cells: dashed/green $=$ dorsal retina; solid/magenta $=$ ventral retina; black, mean \pm SEM). Amplitudes were calculated as the mean leak-subtracted current $100-300 \mathrm{~ms}$ after onset of the preferred stimulus phase; ${ }^{*} p<0.01$. E, Effect of ACET and D-AP5 on excitatory currents in an 0FF- $\alpha$ and an 0 FF- $\delta$ cell. Green indicates response after wash to control condition after additional block with L-AP4. Gray, blue, and magenta show responses under three different stimulus conditions, standard: typical conditions used throughout; dim light: 2 log-unit lower-mean light level; dark: photopic intensity flash against dark background (see Materials and Methods). Inset (bottom, right) shows magnification of the trace above. $\boldsymbol{F}$, Response amplitudes under control conditions and in the presence of ACET and D-AP5 (as in $E$ ) for all recorded cells (OFF- $\alpha: n=4 ; 0 \mathrm{FF}-\delta: n=3)$.

0.004; Fig. $2 A-C$ ). The increased release in GYKI 53655 is likely explained by the loss of inhibitory feedback from horizontal cells and amacrine cells that use AMPARs (i.e., similar to the effect of DNQX above). OFF responses in all layers were eliminated by the KAR antagonists UBP310 $(50 \mu \mathrm{M} ; 0.39 \pm$ 0.08 vs $0.00 \pm 0.01, t=4.57, p=0.020)$ and ACET ( $1 \mu \mathrm{M}$; $0.26 \pm 0.02$ vs $0.01 \pm 0.00, t=14.1, p<0.001$; Pinheiro et al., 2013; Fig. $2 A-C)$. These results strongly suggest that all mouse
OFF bipolar pathways, both transient and sustained, depend on KARs at the cone $\rightarrow$ bipolar cell synapse.

\section{Ganglion cell recordings confirm that both transient and sustained OFF pathways require kainate receptors}

Next, we made a series of electrophysiological measurements to validate the imaging results. First, we confirmed the actions of the AMPAR and KAR antagonists by recording excitatory currents 


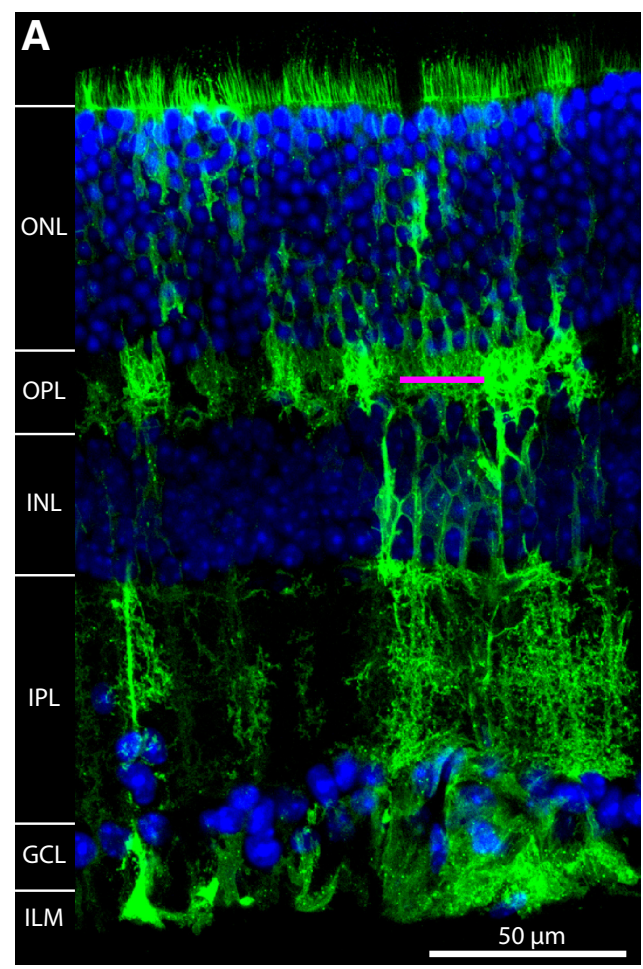

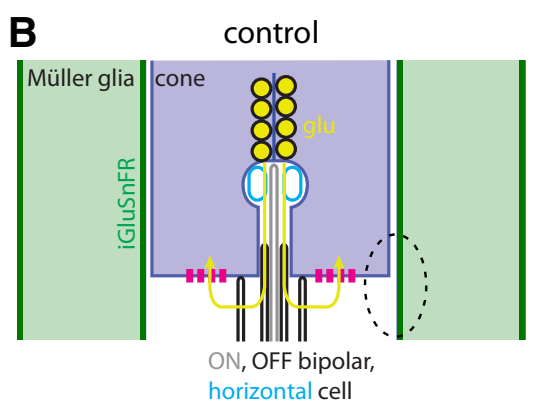

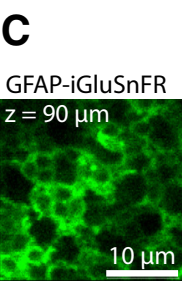

control + wash
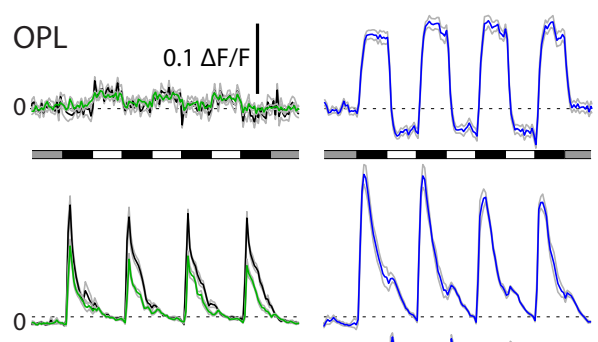

$+\mathrm{L}-\mathrm{AP} 4+\mathrm{UBP} 310$

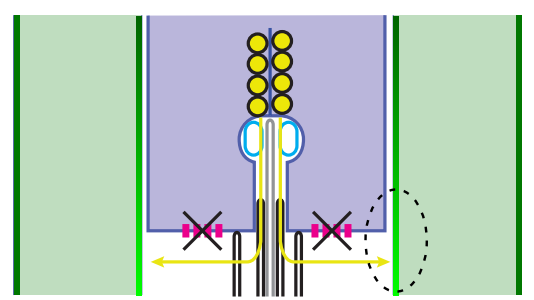

TBOA

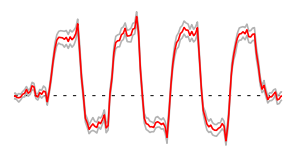

$0.5 \Delta \mathrm{F} / \mathrm{F}$

IPL - OFF

IPL - ON
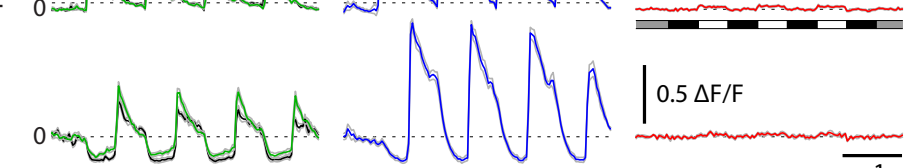

$0.5 \Delta \mathrm{F} / \mathrm{F}$

Figure 4. Synaptic release from photoreceptors persists in the presence of L-AP4 and KAR block. A, Confocal image of a vertical section of the retina $16 \mathrm{~d}$ after transduction with AAV2/1-GFAPiGluSnFR $\left(8 \times 10^{12} \mathrm{IU} / \mu \mathrm{l}\right)$. Blue, Nuclear stain (DAPI); green, iGluSnFR (native fluorescence); ONL, outer nuclear layer; GCL, ganglion cell layer; ILM, inner limiting membrane. Magenta line shows the approximate location of line scans shown in $\boldsymbol{C}$, recorded with two-photon imaging in whole-mount retinas with iGluSnFR expression similar to the retina shown here. $\boldsymbol{B}$, Conceptual model of iGluSnFR activation in the OPL. Under control conditions (left) glutamate is taken up by transporters expressed on presynaptic and postsynaptic (data not shown) neurons; glutamate does not reach the Müller cell processes at sufficient concentrations to evoke a detectable iGluSnFR response. With glutamate uptake blocked (right), the glutamate concentration near the site of synaptic release increases sufficiently to reach Müller cell processes and cause detectible activation of iGluSnFR. Thus, by impairing glutamate uptake, light-evoked glutamate release from photoreceptors can be visualized. C, iGluSnFR fluorescence responses in Müller glia. Under control conditions (left) iGluSnFR responses were only detected in the IPL. Top trace (OPL, two-photon fluorescence image shown at left) shows only moderate modulation caused by low-level bleed-through of stimulus light into the fluorescence detectors. The glutamate transporter blocker TBOA ( $20 \mu \mathrm{m})$ increased the response amplitude and duration in the IPL and revealed light-evoked responses in the OPL (right). Because photoreceptors release at light offset, the evoked response and stimulus artifact apparent during control conditions were of opposite sign. The pharmacological condition that eliminated glutamate release from all bipolar cells (L-AP4 + UBP310; Fig. 2A-C, 3C-D) blocked light-evoked responses in $\mathrm{ON}$ and OFF IPL, but left photoreceptor responses intact (curves show data from a single recording; the same result was observed in $3 / 3$ recordings).

from an $\mathrm{ON} \alpha$ ganglion cell. The bipolar $\rightarrow$ ganglion cell synapse uses primarily AMPARs (Lukasiewicz et al., 1997; Cohen, 2000; Jacoby and $\mathrm{Wu}, 2001$; Beaudoin et al., 2008), whereas the cone $\rightarrow$ ON bipolar synapse uses mGluR6 receptors. We isolated AMPAR- and KAR-mediated currents by eliminating other known sources of excitation. To this end, NMDA and nAch receptors were blocked with D-AP5 $(100 \mu \mathrm{M})$ and hexamethonium $(100 \mu \mathrm{M})$, respectively; these drugs in fact had little effect (Fig. $3 A$ ). Under these conditions, $97.7 \pm 9.0 \%$ of light-evoked responses in ON- $\alpha$ cells were blocked by GYKI $53655(n=4 ; p=$ 0.0008 ; remaining current $18.6 \pm 2.64$ pA; Fig. $3 A, B$ ), with similar remaining currents at 50 and $100 \mu \mathrm{M}$, demonstrating that the concentration used above $(100 \mu \mathrm{M})$ blocked AMPARs adequately. The small GYKI-resistant current (2.3\% of control) was insensitive to KAR block (ACET, $1 \mu \mathrm{M} ; n=1$; data not shown).

Responses measured in the presence of D-AP5 and Hexamethonium were insensitive to subsequently applying KAR antagonists UBP310 $(50 \mu \mathrm{M})$ and ACET $(1 \mu \mathrm{M})(n=4$; mean difference: $0.87 \pm 18.2 \mathrm{pA}, t=0.05, p=0.97$, ns; Fig. $3 A, B)$. Thus, KARs do not mediate light-evoked responses at the $\mathrm{ON}$ bipolar $\rightarrow \mathrm{ON} \alpha$ cell synapse, as expected, and UBP310 and ACET have no apparent effect on AMPARs at the concentrations applied in this study.

If KAR block in the presence of L-AP4 eliminates light-evoked synaptic release from both transient and sustained OFF bipolar cell types, then this should be apparent in the excitatory currents of their postsynaptic ganglion cell targets. To test this, we recorded from OFF- $\alpha$ cells, whose dendrites costratify with transient OFF bipolar cells, and OFF- $\delta$ ganglion cells, whose dendrites costratify with sustained OFF bipolar cells (Fig. 1A; Tagawa et al., 1999; Margolis and Detwiler, 2007; van Wyk et al., 2009). Indeed, in the presence of L-AP4 (to block crossover inhibition), blocking KARs with either ACET or UBP310 eliminated all excitatory responses in both OFF- $\alpha$ and OFF- $\delta$ ganglion cell (OFF $\alpha$ : ventral retina, $n=4,265 \pm 46.0 \mathrm{pA}$ vs $1.74 \pm 0.87 \mathrm{pA}$, $t=5.77, p=0.010$; dorsal retina, $n=5,344 \pm 52.8 \mathrm{pA}$ vs $9.35 \pm$ $2.71 \mathrm{pA}, t=6.46, p=0.003$; OFF- $\delta$ : ventral retina, $n=3,354 \pm$ $32.7 \mathrm{pA}$ vs $25.3 \pm 13.2 \mathrm{pA}, t=9.05, p=0.012$; dorsal retina, $n=$ $7,329 \pm 32.0 \mathrm{pA}$ vs $8.58 \pm 1.49 \mathrm{pA}, t=10.3, p<0.0001$; Fig. $3 C, D)$. Results were consistent between recordings in ventral and dorsal retina, where cones express primarily either S (UVsensitive) or M (green-sensitive) opsin (see Materials and Methods). Combining data from dorsal and ventral retina, KAR antagonists blocked, respectively, 98.2 and $96.0 \%$ of the lightevoked excitatory current in OFF- $\alpha$ cells and OFF- $\delta$ cells. These data show that light-evoked glutamate release from cones activates OFF bipolar cells through kainate receptors.

Next we verified that the absence of excitatory currents in OFF- $\alpha$ and OFF- $\delta$ cells in the presence of L-AP 4 and UBP310 or ACET was not caused by direct block of KARs expressed on the ganglion cells themselves. To test this, we isolated the putative 

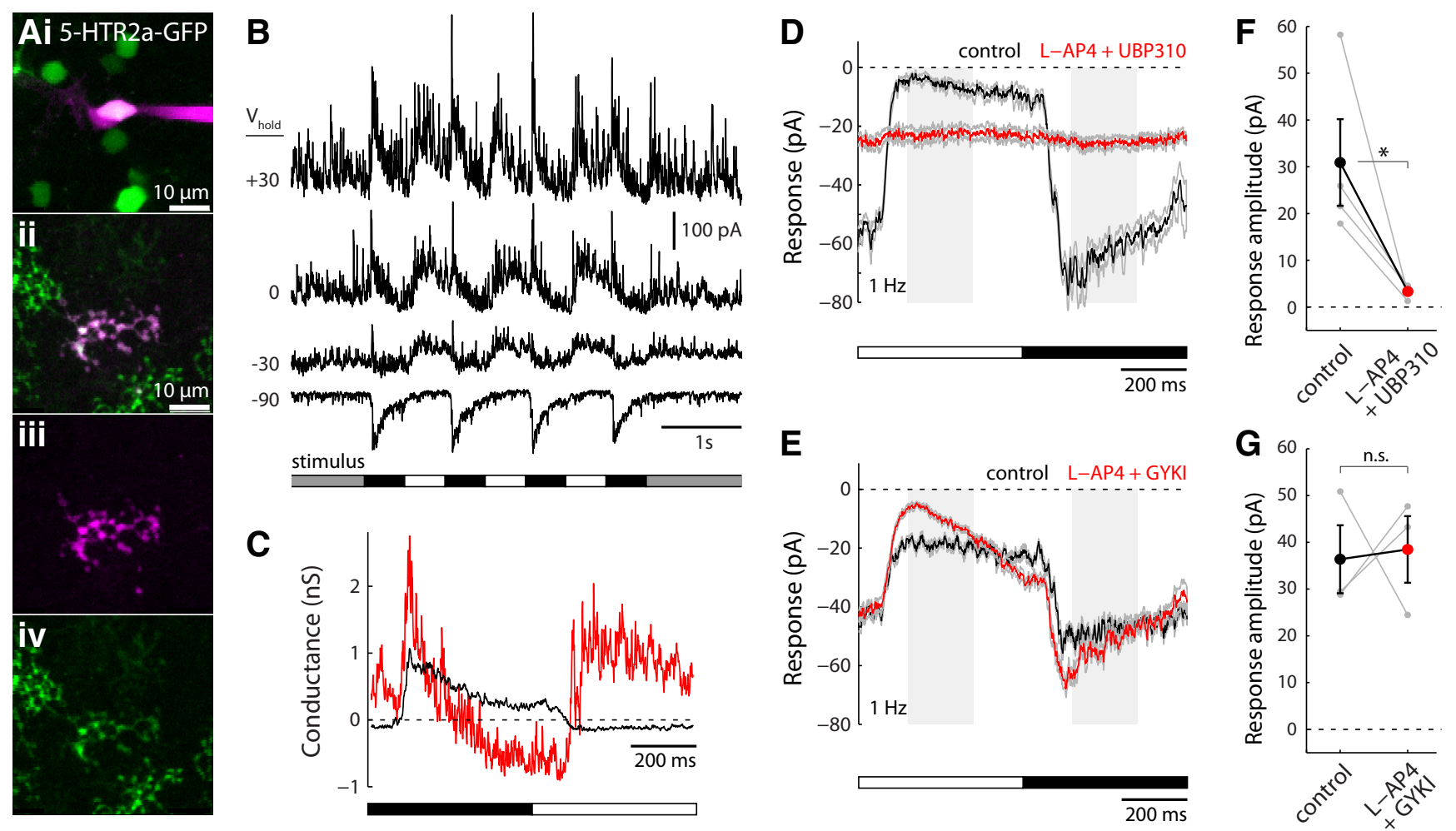

Figure 5. Kainate receptor block eliminates excitatory currents in type-4 0FF bipolar cells. Whole-cell patch-clamp recordings from GFP-expressing type-4 bipolar cells in the whole-mount retina of 5-HTR2a-GFP transgenic mice. Ai, Two-photon fluorescence images of GFP-expressing bipolar cells (green) including the recorded cell. Sulforhodamine 101 in the intracellular solution shows the pipette and recorded cell in magenta; Aii-Aiv, Two-photon image at the level of the type-4 bipolar axon terminal, showing overlay (Aii) and separate views of red (Aiii) and green (Aiv) channels. $B$, Light-evoked current responses at four holding potentials. Type-4 bipolar cells receive inhibition at light $0 \mathrm{FF}$ and at light $0 \mathrm{~N}$; the latter is consistent with crossover inhibition from the $0 \mathrm{~N}$ pathway (Fig. 1). C, Excitatory (black) and inhibitory (red) conductance of the type-4 bipolar cell shown in $A$. Excitatory (inhibitory) conductance was the current recorded at $E_{\mathrm{CI}}\left(E_{\text {cation }}\right)$ divided by the driving force, $-67 \mathrm{mV}(+67 \mathrm{mV})$. D. Excitatory currents evoked by a $1 \mathrm{~Hz}$, temporal square wave stimulus. Bath application of L-AP4 and the KAR antagonist UBP310 (50 $\mu \mathrm{M})$ blocked the response. $E$, Light-evoked excitatory currents persisted in the presence of L-AP4 and the AMPAR antagonist GYKI53655 (100 $\mu \mathrm{M})$.F, G, Response amplitudes in control and drug conditions for all recorded type-4 cells (KAR block, $n=4$; AMPAR block, $n=3$ ). Gray lines show individual cells, black lines show mean $\pm \mathrm{SEM} ;{ }^{*} p<0.05$.

AMPAR-mediated response in the ganglion cells by pharmacological block of KARs and NMDARs (ACET, $1.0 \mu \mathrm{M}$; D-AP5, 100 $\mu \mathrm{M})$. Under this condition, excitatory currents in OFF- $\alpha$ and OFF- $\delta$ cells persisted (mean difference for OFF- $\alpha: 2.96 \pm 19.8$ $\mathrm{pA}, t=0.15, p=0.89$, n.s.; OFF- $\delta:-30.8 \pm 18.9 \mathrm{pA}, t=1.63$, $p=0.24$, ns; Fig. $3 E, F)$. These currents presumably reflected ON pathway-mediated OFF bipolar release onto the ganglion cells' AMPARs. Indeed, these currents were suppressed by subsequently blocking ON-pathway crossover inhibition with L-AP4 (Fig. 3E). In the latter condition, not only was the response to our standard stimulus (high contrast on a photopic background) blocked, additional stimuli, including contrast modulation at a reduced mean level (by two log units; $n=3$ ) and photopic flashes on a dark background ( $n=4$; Fig. $3 E$ ), also failed to generate a detectable response.

These data confirm the imaging results and suggest that both transient and sustained OFF bipolar pathways rely on KARs at the cone $\rightarrow$ OFF bipolar synapse. Strong evoked release at the level of the photoreceptors does not cause AMPAR-mediated activation of either transient or sustained OFF bipolar cells sufficient to evoke synaptic release.

\section{Cone photoreceptor release persists with kainate receptors blocked}

We next tested the possibility that the combination of L-AP4 and KAR block indirectly suppressed glutamate release at the level of the cone synapse. We visualized glutamate signaling in both the outer plexiform layer (OPL) and IPL by selectively targeting iGluSnFR expression to Müller glia, using the GFAP (glial fibrillary acidic protein) promoter (Borghuis et al., 2013). Müller glia extend vertically across the entire retina with dense local branching in the OPL and IPL (Fig. 4A). Under control conditions, Müller glia processes were exposed to glutamate in the IPL (strong fluorescence responses) but not in the OPL (no fluorescence responses; Fig. $4 B, C$ ). In the OPL, glutamate uptake apparently occurs through a glia-independent, neural mechanism and is efficient enough to prevent glutamate exposure to the Müller glia processes (Hasegawa et al., 2006). However, stimulus-evoked glutamate release in the OPL could be visualized after bath applying the nonspecific glutamate transporter blocker TBOA $(20 \mu \mathrm{M}$; Fig. 4C).

By blocking glutamate uptake, TBOA increased glutamate concentrations near photoreceptor synaptic release sites enough to expose iGluSnFR on nearby Müller cell processes (Fig. 4B). As expected, TBOA also increased the amplitude and duration of ON and OFF responses in the IPL (Fig. 4C; Marvin et al., 2013). In the presence of TBOA, application of L-AP4 and UBP310 eliminated all stimulus-evoked glutamate release from $\mathrm{ON}$ and OFF bipolar cells measured at Müller cell processes in the IPL, but did not block stimulus-evoked glutamate release from photoreceptors measured at Müller cell processes in the OPL (Fig. 4C). These data show that cone glutamate release persists in the presence of L-AP4 and KAR block. Furthermore, they also demonstrate that UBP310, like other glutamate receptor antagonists 
A

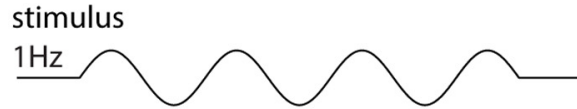

\section{ON alpha}

0 -
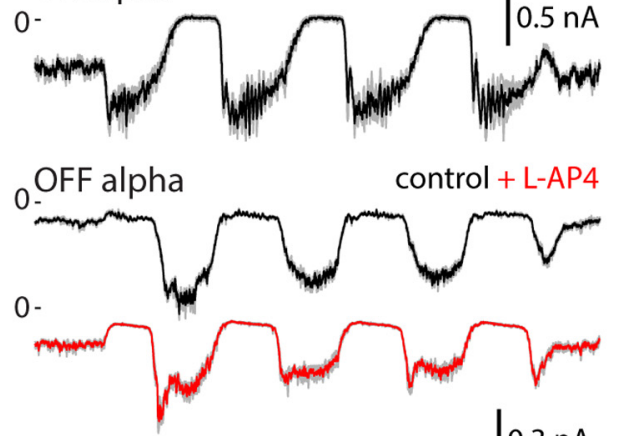
$0.3 \mathrm{nA}$

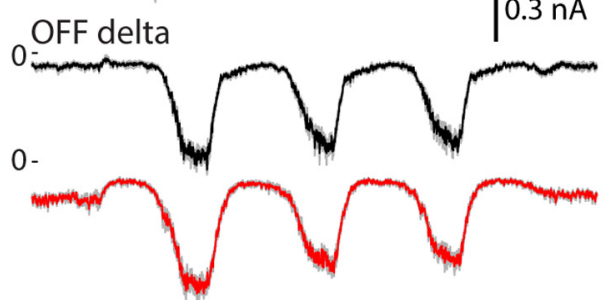

C ON layer

control
20

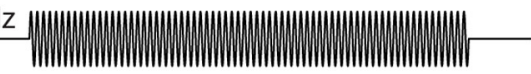

0 menting

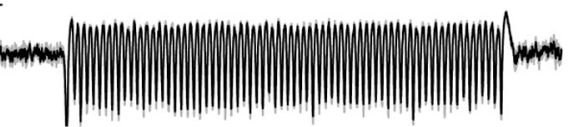

0 -

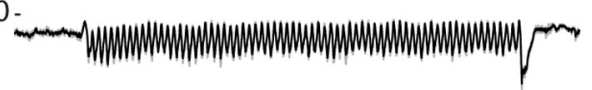

0 -

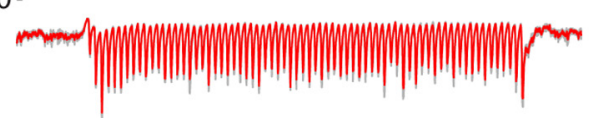

0 -

0 -

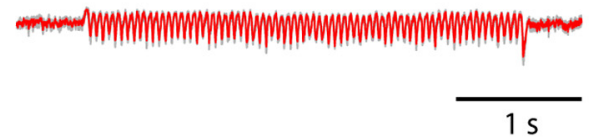

L-AP4

$\mathrm{L}-\mathrm{AP} 4+\mathrm{GYKI}$
B
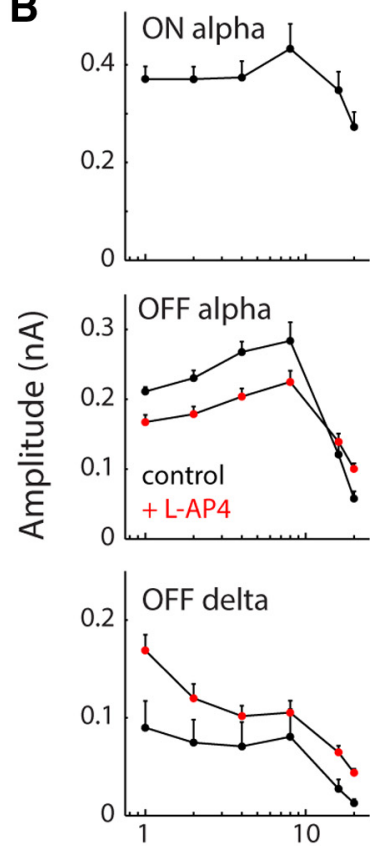

Frequency $(\mathrm{Hz})$

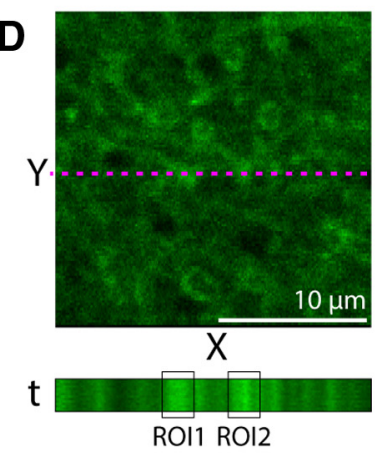

E

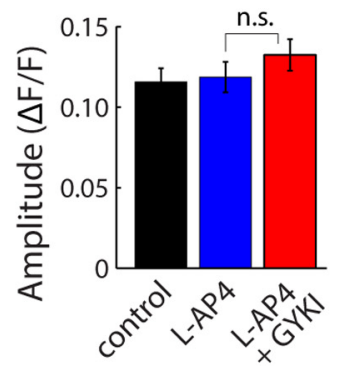

Figure 6. Kainate receptors on OFF bipolar cell dendrites support fast temporal processing. $\boldsymbol{A}$, Whole-cell patch-clamp recordings of excitatory currents in $0 \mathrm{~N}$ - $\alpha$, $0 \mathrm{FF}$ - $\alpha$, and $0 \mathrm{FF}-\delta$ ganglion cells stimulated with sinusoidal light modulation under control conditions (black) and in L-AP4 (red). Blocking the ON pathway did not suppress responses to $20 \mathrm{~Hz}$ modulation. $\boldsymbol{B}$, Temporal tuning curves of OFF- $\alpha, 0 \mathrm{FF}-\delta$, and $0 \mathrm{~N}-\alpha$ cells (black: control; red: L-AP4). C, iGluSnFR fluorescence responses to 1.0 and $7.5 \mathrm{~Hz}$ square-wave stimulation, measured with $2.0 \mathrm{kHz}$ line scans at the level of $0 \mathrm{~N}$ and OFF bipolar cell output ( $z=16$ and $32 \mu \mathrm{m}$, respectively). Trials $1-3$ show the response to three consecutive stimulus presentations for each condition; $1.0 \mathrm{~Hz}$ stimulus shown for control condition only. L-AP4 blocked release in the ON layers. In the OFF layer, $7.5 \mathrm{~Hz}$ responses persisted in the presence of L-AP4 and the AMPAR blocker GYKI53655 (100 $\mu$ M). D, Fluorescence image at the level of the OFF IPL $(z=32 \mu \mathrm{m})$ with line scan location (magenta); X-time $(t)$ plot with example ROls indicated is shown below image. $\boldsymbol{E}$, Average amplitude ( \pm SEM) during 7.5 Hz modulation across conditions ( $n=60$ ROls; see Materials and Methods for definition). n.s., $p=0.32$.

(Marvin et al., 2013), does not affect iGluSnFR function. Even with transporters blocked, and glutamate spillover in the OPL increased, we did not detect AMPAR-mediated glutamate release from OFF bipolar cells, whereas KARs were required for the function of all OFF-type bipolar cells. Therefore, glutamate spillover in the OPL is not sufficient for evoking AMPAR-mediated responses in OFF bipolar cells.
Cone to type- 4 OFF bipolar cell synapses rely on kainate receptors

To further substantiate the role of KARs in OFF bipolar cell responses, we made direct recordings of light-evoked excitatory currents in OFF bipolar cells in the whole-mount retina. Type-4 OFF bipolar cells reportedly express both AMPARs and KARs (Puller et al., 2013), based on agonist application, and these cells 
can be selectively targeted for recording in the 5HTR2a-GFP line (Lu et al., 2009). A GFP + cell was recorded with a patch pipette filled with red dye; following recording, the green cell showed red fluorescence, and the filled axon terminal fitted an apparent mosaic of neighboring GFP + terminals in the IPL (Fig. 5A). Type-4 cells showed characteristic changes in their light-evoked currents at varying holding potentials (Fig. $5 B$ ), including an excitatory conductance at light offset, and an inhibitory conductance at both light offset and onset (Fig. 5C). The inhibition at light onset is direct evidence for crossover inhibition from the ON pathway. In the presence of L-AP4, the KAR antagonist UBP310 (50 $\mu \mathrm{M})$ blocked the excitatory response $(n=4 ; 30.9 \pm 9.3 \mathrm{pA}$ vs $3.3 \pm$ $0.76 \mathrm{pA}$; mean difference $27.6 \pm 9.3 \mathrm{pA}, t=2.97, p=0.029$; Fig. $5 D, F)$.

Next we recorded from type- 4 bipolar cells and applied L-AP4 and the AMPAR antagonist GYKI $53655(100 \mu \mathrm{M})$. Although there was some variability in the response in GYKI, as expected during prolonged whole-cell recording from bipolar cells in the intact retina, on average the response was not changed from the control condition $(n=3$; mean difference $2.09 \pm 14.3 \mathrm{pA}, t=$ $0.146, p=0.90$, ns; Fig. $5 E, G$ ). These measurements support the imaging results and demonstrate that the cone $\rightarrow$ OFF bipolar synapse of the type- 4 bipolar cell is directly dependent on KARs, with no apparent contribution from AMPARs.

\section{Kainate receptors support rapid temporal processing in OFF bipolar cell pathways}

KARs are known for having slow kinetics at many CNS synapses (Castillo et al., 1997; Vignes and Collingridge, 1997; Erreger et al., 2004; Copits and Swanson, 2012; Tomita and Castillo, 2012). Accordingly, paired synaptic recordings of cones and individual OFF bipolar cells in the ground squirrel retina suggested a slow time constant for recovery from desensitization, $\sim 0.5-2 \mathrm{~s}$ (DeVries and Schwartz, 1999; DeVries, 2000; Straub et al., 2011). This slow recovery suggested that KARs might be inadequate for encoding of high temporal frequencies, but in fact, high-frequencies are commonly encoded by sustained visual pathways. For example, sustained ganglion cells in cat ( $\beta / \mathrm{X}$-type) and monkey (midget/parvocellular-type) encode temporal frequencies $>30$ $\mathrm{Hz}$ (Frishman et al., 1987; Lee et al., 1990). Our results in Figure 1 show that $\mathrm{ON}$-pathway crossover inhibition can modulate release from OFF bipolar terminals. Conceivably, this crossover pathway, rather than direct cone input, mediates rapid modulation of KAR-expressing OFF bipolar cells. To test whether OFF bipolar cells inherit their fast temporal kinetics from the ONpathway, we measured OFF bipolar cell output in response to high temporal frequencies in the absence of crossover inhibition by the ON pathway.

Under control conditions, excitatory currents in ganglion cells responded to sine-wave modulation at frequencies up to 20 $\mathrm{Hz}$, with a peak near $8 \mathrm{~Hz}$ (Fig. $6 A, B)$. ON- $\alpha(n=8)$ and OFF- $\alpha$ $(n=7)$ cells showed similar tuning; whereas OFF- $\delta(n=4)$ cells showed low-pass tuning, and lower response amplitudes compared with the $\alpha$ cells (Fig. 6B). Blocking ON bipolar cellmediated crossover inhibition, with L-AP4 $(20 \mu \mathrm{M})$, altered the tuning curve of OFF- $\alpha$ cells, decreasing the response at lowfrequencies and increasing the response at high frequencies. L-AP4 increased the response in OFF- $\delta$ cells at all frequencies. The different effects of L-AP4 on OFF- $\alpha$ and $-\delta$ cells implies that distinct presynaptic circuits, each with a diverse influence from the ON-pathway, converge onto the presynaptic bipolar terminals; this would include more complicated circuits than that depicted in Figure $1 F$. Importantly, in both OFF- $\alpha$ and OFF- $\delta$ cells, the response at the highest temporal frequency tested $(20 \mathrm{~Hz})$ persisted in the presence of L-AP4 (Fig. $6 B$ ) and was significantly greater than zero (OFF- $\alpha$ : $100 \pm 7.8 \mathrm{pA}, t=13.0, p<0.0001$; OFF- $\delta$ : $44.2 \pm 5.2 \mathrm{pA}, t=8.6, p<0.0001)$. Hence, the fast temporal kinetics of OFF bipolar cell release onto ganglion cells does not rely on the ON bipolar cell pathway through crossover inhibition. Instead, KARs on OFF bipolar cells mediate fast visual processing.

We verified with iGluSnFR measurements that KARs mediated OFF bipolar responses to $7.5 \mathrm{~Hz}$ stimulation. This frequency approximates the peak of the tuning curves of $\alpha$ cells and falls within the resolution limit of iGluSnFR (temporal cutoff $\sim 15$ $\mathrm{Hz}$ ). Line scans across bipolar cell axon terminals showed response modulation at $7.5 \mathrm{~Hz}$ in the $\mathrm{ON}$ and OFF layers of the IPL (Fig. 6C,D). Responses in OFF layers persisted after blocking ONpathway crossover inhibition (L-AP4, $20 \mu \mathrm{M})$ and AMPARs (GYKI53655,100 $\mu \mathrm{M}$; Fig. 6C,E): $0.13 \pm 0.01 \Delta \mathrm{F} / \mathrm{F}$. These results demonstrate that transmission of this temporal frequency from cones to OFF bipolar cells does not require AMPARs. Furthermore, because KAR block eliminates all synaptic activity in OFF bipolar cells, we conclude that KAR signaling is the principal mechanism underlying cone-driven bipolar cell activation, including responses at high temporal frequencies.

\section{Discussion}

A prevailing theory proposes that differential expression of AMPARs and KARs at OFF bipolar cell dendrites generates parallel fast/transient and slow/sustained pathways for vision in the mammalian retina (DeVries, 2000; DeVries et al., 2006; Masland, 2012; Sterling, 2013). Here, we tested this hypothesis in the mouse retina, using light-evoked synaptic stimulation, two-photon imaging of iGluSnFR, patch-clamp recording of ganglion cells and bipolar cells, and pharmacological perturbations. Our results show that the transient and sustained OFF pathways in the mouse retina are not mediated by differential expression of AMPARs and KARs. Instead, all OFF pathways (evaluated with crossover inhibition blocked; Fig. 1) depend critically on KARs (Figs. 2-5). Results were consistent across multiple conditions, including: different mean light and contrast levels (Fig. $3 E$ ); different halves of the retina, where cones express primarily either $\mathrm{M}$ or S opsin (Fig. 3D); and in the presence of glutamate transporter block, which increases spillover (Fig. 4). If there are any conditions where AMPARs contribute substantially to OFF bipolar pathways in mouse, they must be outside of the range we tested and possibly require long-term changes in receptor expression associated with prolonged exposure to specific stimulus conditions (Jones et al., 2012).

Our results show that OFF bipolar cell KARs support responses to high-frequency light-evoked synaptic stimulation in the physiological range (up to $20 \mathrm{~Hz}$ ). Notably, both the transient and sustained OFF pathways, which converge onto OFF- $\alpha$ and OFF- $\delta$ ganglion cell types, followed $20 \mathrm{~Hz}$ modulation (Fig. 6). Hence, KAR signaling in OFF bipolar cells is not limited to slow synaptic integration, as has been demonstrated elsewhere in the nervous system (Castillo et al., 1997; Vignes and Collingridge, 1997; Copits and Swanson, 2012; Tomita and Castillo, 2012).

Using a fluorescent biosensor for glutamate, we show for the first time that crossover inhibition from the ON pathway controls glutamate release from OFF bipolar terminals at all levels of the IPL (Fig. 1). This suggests a complementary role for cone $\rightarrow$ OFF bipolar cell and ON amacrine $\rightarrow$ OFF bipolar cell synapses in modulating glutamate release from OFF bipolar cells. Crossover inhibition has been observed directly in some rabbit and mouse 
bipolar cells (Molnar and Werblin, 2007; Pang et al., 2012) and was implied by pharmacological experiments in rabbit OFF brisk-sustained ganglion cells (Buldyrev et al., 2012). Crossover inhibition likely plays a prominent role in generating distinct responses across OFF bipolar cell types.

A model that emphasizes the importance of AMPARs for fast/ transient OFF pathways was supported at the functional level primarily by data from the ground squirrel retina (DeVries, 2000). In response to S-cone, M-cone, or rod depolarization, a type-b2 OFF bipolar cell's response was blocked by GYKI (Li and DeVries, 2006; Li et al., 2010). To our knowledge, there is limited additional functional evidence for OFF bipolar cells whose light response depends predominantly on AMPARs. In rabbit, OFF bipolar cells of unknown type were mostly blocked (77-86\%) by UBP310 $(10 \mu \mathrm{M})$, with a minor component blocked by GYKI (10-20\%; Buldyrev et al., 2012). Some mouse bipolar cell types showed a GYKI-sensitive response to direct AMPA application (Puller et al., 2013). However, experiments with puff-applied agonists should be interpreted with caution. For example, GFP+ type-4 bipolar cells in the 5-HTR2a mouse retina showed GYKIinsensitive, KAR-mediated light responses in our study (Fig. 5) but mixed AMPAR/KAR-mediated responses to puff-applied agonists in a previous study (Puller et al., 2013). Direct application of glutamate receptor agonists might activate nonsynaptic receptors (including AMPARs) on OFF bipolar cells that are not stimulated during synaptic glutamate release from cones, or, alternatively, act through an indirect pathway involving horizontal cells, which express AMPARs and feedback onto cones. Some salamander OFF bipolar cell light-evoked responses were completely blocked by GYKI (Cadetti et al., 2005), emphasizing that expression patterns may differ across species.

The second line of evidence for AMPARs on mammalian OFF bipolar cells comes from anatomical studies, performed across several species (Morigiwa and Vardi, 1999; Haverkamp and Wässle, 2000; Li et al., 2004; Puller et al., 2007). It is difficult to fully evaluate this evidence for two reasons. First, in most studies the specificity of the antibodies was untested (Rhodes and Trimmer, 2006). Second, even if the antibodies were specific, confocal fluorescence imaging does not permit differentiating AMPARs expressed on horizontal cells, which terminate near the ribbon release sites in invaginations, from AMPARs expressed by OFF bipolar terminals, whose dendrites in squirrel are semiinvaginating (DeVries et al., 2006). Previous studies in mouse showed apparent AMPAR expression in basal (noninvaginating) contacts on both rod and cone photoreceptors (Hack et al., 1999, 2001), but our functional measurements offer no support for a role of AMPARs at these conventional sites of OFF bipolar cell dendrites. AMPARs and KARs appear to form layers beneath the cone pedicle (Haverkamp et al., 2000), but some of these layers may include nonsynaptic receptors, as described above. Importantly, several studies also demonstrated AMPAR expression on ON bipolar cell dendrites (including rod bipolar cell dendrites), but there are no light-evoked AMPAR-mediated currents in ON bipolar cells (Hughes et al., 1992; Morigiwa and Vardi, 1999; Hack et al., 2001).

We propose an alternative model for parallel OFF pathways in the retina, where both transient and sustained bipolar cells use kainate, but not AMPA, receptors. How can KARs, with their slow recovery from desensitization, function in the presence of tonic synaptic release from the photoreceptors, and how can they mediate transient responses and fast temporal processing? Cones typically rest near $-35 \mathrm{mV}$ and have ongoing release of $\sim 20-40$ vesicles synapse ${ }^{-1}$ second $^{-1}$ (Ashmore and Copenhagen, 1983;
DeVries et al., 2006; Jackman et al., 2009). Thus, the time constant of the KARs' recovery from desensitization $(\sim 0.5-2 \mathrm{~s}$; DeVries and Schwartz, 1999; DeVries, 2000; Straub et al., 2011) is approximately an order of magnitude longer than the average interval between quantal events $(\sim 25-50 \mathrm{~ms})$. KARs would therefore operate primarily in a desensitized state, with only a fraction of channels capable of mediating current for a given quantal event at each synapse. Indeed, this explains the relatively small, tonic currents measured in KAR-expressing OFF bipolar cells when a presynaptic cone is clamped at $-35 \mathrm{mV}$ (DeVries and Schwartz, 1999; DeVries et al., 2006). However, the combined current from all 5-10 presynaptic cones (Wässle et al., 2009) (order of 10-100 pA) is sufficient to modulate the OFF bipolar cell's membrane voltage throughout the physiological range (DeVries and Schwartz, 1999). Thus, under physiological levels of cone depolarization, an OFF bipolar cell's KARs would faithfully report the presynaptic glutamate release rate, with relatively stable quantal response amplitudes at each synapse.

How do OFF bipolar cell KARs encode high temporal frequencies in the presence of persistent desensitization? The limitation on temporal resolution depends not on the time constant for recovery of the desensitized receptors, but rather on the time constant of receptor deactivation for the nondesensitized receptors, estimated to be 15-20 ms (DeVries and Schwartz, 1999; Straub et al., 2011). This allows encoding most of the conemediated operating range, which in mouse extends to $\sim 30 \mathrm{~Hz}$ (i.e., $33 \mathrm{~ms} \mathrm{cycle}^{-1}$; Wang et al., 2011). A glutamate receptor's recovery from desensitization would play a substantial role in signaling only for stimuli strong enough, and for frequencies low enough, to suppress glutamate substantially for a prolonged period of time. As an example, AMPARs on the ground squirrel's b2 bipolar cell at bright light levels would apparently recover from desensitization during stimulation at a temporal frequency that suppresses glutamate release for $>100 \mathrm{~ms}$ (DeVries, 2000).

For mouse and other mammals that lack AMPARs at the cone $\rightarrow$ OFF bipolar cell synapse, the division between transient and sustained signaling must depend on alternative mechanisms, and our data support this: block of iGluRs apparently removed inhibitory feedback, and the lack of amacrine signaling caused sustained OFF release to become transient (Figs. 1D, 2A). Additional shaping of release kinetics could be implemented at the bipolar cell's ribbon synapse; diversity between bipolar pathways would then follow from differences in resting potential and accompanying differences in vesicle depletion (Jarsky et al., 2011; Ke et al., 2014). It remains to be determined whether responses of the fastest OFF bipolar cell types in mouse are aided by selective expression of KARs with fast kinetics through specific receptor subunit combinations, splice isoforms, and the inclusion or exclusion of auxiliary proteins (Contractor et al., 2003; Straub et al., 2011; Tang et al., 2011; Copits and Swanson, 2012; Tomita and Castillo, 2012).

\section{References}

Applebury ML, Antoch MP, Baxter LC, Chun LL, Falk JD, Farhangfar F, Kage K, Krzystolik MG, Lyass LA, Robbins JT (2000) The murine cone photoreceptor: a single cone type expresses both $S$ and $M$ opsins with retinal spatial patterning. Neuron 27:513-523. Medline

Arman AC, Sampath AP (2012) Dark-adapted response threshold of OFF ganglion cells is not set by OFF bipolar cells in the mouse retina. J Neurophysiol 107:2649-2659. CrossRef Medline

Ashmore JF, Copenhagen DR (1983) An analysis of transmission from cones to hyperpolarizing bipolar cells in the retina of the turtle. J Physiol 340:569-597. Medline

Awatramani GB, Slaughter MM (2001) Intensity-dependent, rapid activa- 
tion of presynaptic metabotropic glutamate receptors at a central synapse. J Neurosci 21:741-749. Medline

Baden T, Berens P, Bethge M, Euler T (2013) Spikes in mammalian bipolar cells support temporal layering of the inner retina. Curr Biol 23:48-52. CrossRef Medline

Beaudoin DL, Manookin MB, Demb JB (2008) Distinct expressions of contrast gain control in parallel synaptic pathways converging on a retinal ganglion cell. J Physiol 586:5487-5502. CrossRef Medline

Borghuis BG, Marvin JS, Looger LL, Demb JB (2013) Two-photon imaging of nonlinear glutamate release dynamics at bipolar cell synapses in the mouse retina. J Neurosci 33:10972-10985. CrossRef Medline

Breuninger T, Puller C, Haverkamp S, Euler T (2011) Chromatic bipolar cell pathways in the mouse retina. J Neurosci 31:6504-6517. CrossRef Medline

Buldyrev I, Puthussery T, Taylor WR (2012) Synaptic pathways that shape the excitatory drive in an OFF retinal ganglion cell. J Neurophysiol 107: 1795-1807. CrossRef Medline

Cadetti L, Tranchina D, Thoreson WB (2005) A comparison of release kinetics and glutamate receptor properties in shaping rod-cone differences in EPSC kinetics in the salamander retina. J Physiol 569:773-788. CrossRef Medline

Castillo PE, Malenka RC, Nicoll RA (1997) Kainate receptors mediate a slow postsynaptic current in hippocampal CA3 neurons. Nature 388:182-186. CrossRef Medline

Cohen E, Sterling P (1990) Demonstration of cell types among cone bipolar neurons of cat retina. Philos Trans R Soc Lond B Biol Sci 330:305-321. CrossRef Medline

Cohen ED (2000) Light-evoked excitatory synaptic currents of X-type retinal ganglion cells. J Neurophysiol 83:3217-3229. Medline

Contractor A, Sailer AW, Darstein M, Maron C, Xu J, Swanson GT, Heinemann SF (2003) Loss of kainate receptor-mediated heterosynaptic facilitation of mossy-fiber synapses in KA2 ${ }^{-1-}$ mice. J Neurosci 23:422-429. Medline

Copits BA, Swanson GT (2012) Dancing partners at the synapse: auxiliary subunits that shape kainate receptor function. Nat Rev Neurosci 13:675686. CrossRef Medline

Cui J, Ivanova E, Qi L, Pan ZH (2012) Expression of CaV3.2 T-type Ca(2) $(+)$ channels in a subpopulation of retinal type- 3 cone bipolar cells. Neuroscience 224:63-69. CrossRef Medline

DeVries SH (2000) Bipolar cells use kainate and AMPA receptors to filter visual information into separate channels. Neuron 28:847-856. CrossRef Medline

DeVries SH, Schwartz EA (1999) Kainate receptors mediate synaptic transmission between cones and "off" bipolar cells in a mammalian retina. Nature 397:157-160. CrossRef Medline

DeVries SH, Li W, Saszik S (2006) Parallel processing in two transmitter microenvironments at the cone photoreceptor synapse. Neuron 50:735748. CrossRef Medline

Eggers ED, Lukasiewicz PD (2011) Multiple pathways of inhibition shape bipolar cell responses in the retina. Vis Neurosci 28:95-108. CrossRef Medline

Erreger K, Chen PE, Wyllie DJ, Traynelis SF (2004) Glutamate receptor gating. Crit Rev Neurobiol 16:187-224. CrossRef Medline

Frishman LJ, Freeman AW, Troy JB, Schweitzer-Tong DE, Enroth-Cugell C (1987) Spatiotemporal frequency responses of cat retinal ganglion cells. J Gen Physiol 89:599-628. CrossRef Medline

Hack I, Peichl L, Brandstätter JH (1999) An alternative pathway for rod signals in the rodent retina: rod photoreceptors, cone bipolar cells, and the localization of glutamate receptors. Proc Natl Acad Sci U S A 96: 14130-14135. CrossRef Medline

Hack I, Frech M, Dick O, Peichl L, Brandstätter JH (2001) Heterogeneous distribution of AMPA glutamate receptor subunits at the photoreceptor synapses of rodent retina. Eur J Neurosci 13:15-24. CrossRef Medline

Hasegawa J, Obara T, Tanaka K, Tachibana M (2006) High-density presynaptic transporters are required for glutamate removal from the first visual synapse. Neuron 50:63-74. CrossRef Medline

Haverkamp S, Wässle H (2000) Immunocytochemical analysis of the mouse retina. J Comp Neurol 424:1-23. CrossRef Medline

Haverkamp S, Grünert U, Wässle H (2000) The cone pedicle, a complex synapse in the retina. Neuron 27:85-95. CrossRef Medline

Hughes TE, Hermans-Borgmeyer I, Heinemann S (1992) Differential ex- pression of glutamate receptor genes (GluR1-5) in the rat retina. Vis Neurosci 8:49-55. CrossRef Medline

Ivanova E, Müller U, Wässle H (2006) Characterization of the glycinergic input to bipolar cells of the mouse retina. Eur J Neurosci 23:350-364. CrossRef Medline

Jackman SL, Choi SY, Thoreson WB, Rabl K, Bartoletti TM, Kramer RH (2009) Role of the synaptic ribbon in transmitting the cone light response. Nat Neurosci 12:303-310. CrossRef Medline

Jacoby RA, Wu SM (2001) AMPA-preferring receptors mediate excitatory non-NMDA responses of primate retinal ganglion cells. Vis Neurosci 18:703-710. Medline

Jarsky T, Cembrowski M, Logan SM, Kath WL, Riecke H, Demb JB, Singer JH (2011) A synaptic mechanism for retinal adaptation to luminance and contrast. J Neurosci 31:11003-11015. CrossRef Medline

Jones RS, Carroll RC, Nawy S (2012) Light-induced plasticity of synaptic AMPA receptor composition in retinal ganglion cells. Neuron 75:467478. CrossRef Medline

Ke JB, Wang YV, Borghuis BG, Cembrowski MS, Riecke H, Kath WL, Demb JB, Singer JH (2014) Adaptation to background light enables contrast coding at rod bipolar cell synapses. Neuron 81:388-401. CrossRef Medline

Kouyama N, Marshak DW (1992) Bipolar cells specific for blue cones in the macaque retina. J Neurosci 12:1233-1252. Medline

Lee BB, Pokorny J, Smith VC, Martin PR, Valberg A (1990) Luminance and chromatic modulation sensitivity of macaque ganglion cells and human observers. J Opt Soc Am A 7:2223-2236. CrossRef Medline

Li W, DeVries SH (2006) Bipolar cell pathways for color and luminance vision in a dichromatic mammalian retina. Nat Neurosci 9:669-675. CrossRef Medline

Li W, Keung JW, Massey SC (2004) Direct synaptic connections between rods and OFF cone bipolar cells in the rabbit retina. J Comp Neurol 474:1-12. CrossRef Medline

Li W, Chen S, DeVries SH (2010) A fast rod photoreceptor signaling pathway in the mammalian retina. Nat Neurosci 13:414-416. CrossRef Medline

Lindstrom SH, Ryan DG, Shi J, Devries SH (2014) Kainate receptor subunit diversity underlying response diversity in retinal off bipolar cells. J Physiol, in press. CrossRef Medline

Lu Q, Ivanova E, Pan ZH (2009) Characterization of green fluorescent protein-expressing retinal cone bipolar cells in a 5-hydroxytryptamine receptor 2a transgenic mouse line. Neuroscience 163:662-668. CrossRef Medline

Lukasiewicz PD, Wilson JA, Lawrence JE (1997) AMPA-preferring receptors mediate excitatory synaptic inputs to retinal ganglion cells. J Neurophysiol 77:57-64. Medline

Margolis DJ, Detwiler PB (2007) Different mechanisms generate maintained activity in ON and OFF retinal ganglion cells. J Neurosci 27:59946005. CrossRef Medline

Marvin JS, Borghuis BG, Tian L, Cichon J, Harnett MT, Akerboom J, Gordus A, Renninger SL, Chen TW, Bargmann CI, Orger MB, Schreiter ER, Demb JB, Gan WB, Hires SA, Looger LL (2013) An optimized fluorescent probe for visualizing glutamate neurotransmission. Nat Methods 10:162-170. CrossRef Medline

Masland RH (2012) The neuronal organization of the retina. Neuron 76: 266-280. CrossRef Medline

Molnar A, Werblin F (2007) Inhibitory feedback shapes bipolar cell responses in the rabbit retina. J Neurophysiol 98:3423-3435. CrossRef Medline

Morgans CW, Zhang J, Jeffrey BG, Nelson SM, Burke NS, Duvoisin RM, Brown RL (2009) TRPM1 is required for the depolarizing light response in retinal ON-bipolar cells. Proc Natl Acad Sci U S A 106:19174-19178. CrossRef Medline

Morigiwa K, Vardi N (1999) Differential expression of ionotropic glutamate receptor subunits in the outer retina. J Comp Neurol 405:173-184. CrossRef Medline

Nakajima Y, Iwakabe H, Akazawa C, Nawa H, Shigemoto R, Mizuno N, Nakanishi S (1993) Molecular characterization of a novel retinal metabotropic glutamate receptor mGluR6 with a high agonist selectivity for L-2-amino-4-phosphonobutyrate. J Biol Chem 268:11868-11873. Medline

Nikonov SS, Kholodenko R, Lem J, Pugh EN Jr (2006) Physiological features 
of the S- and M-cone photoreceptors of wild-type mice from single-cell recordings. J Gen Physiol 127:359-374. CrossRef Medline

Pang JJ, Gao F, Wu SM (2012) Physiological characterization and functional heterogeneity of narrow-field mammalian amacrine cells. J Physiol 590:223-234. CrossRef Medline

Pinheiro PS, Lanore F, Veran J, Artinian J, Blanchet C, Crépel V, Perrais D, Mulle C (2013) Selective block of postsynaptic kainate receptors reveals their function at hippocampal mossy fiber synapses. Cereb Cortex 23: 323-331. CrossRef Medline

Pologruto TA, Sabatini BL, Svoboda K (2003) ScanImage: flexible software for operating laser scanning microscopes. Biomed Eng Online 2:13. CrossRef Medline

Puller C, Haverkamp S, Grünert U (2007) OFF midget bipolar cells in the retina of the marmoset, Callithrix jacchus, express AMPA receptors. J Comp Neurol 502:442-454. CrossRef Medline

Puller C, Ivanova E, Euler T, Haverkamp S, Schubert T (2013) OFF bipolar cells express distinct types of dendritic glutamate receptors in the mouse retina. Neuroscience 243:136-148. CrossRef Medline

Rhodes KJ, Trimmer JS (2006) Antibodies as valuable neuroscience research tools versus reagents of mass distraction. J Neurosci 26:8017-8020. CrossRef Medline

Röhlich P, van Veen T, Szél A (1994) Two different visual pigments in one retinal cone cell. Neuron 13:1159-1166. CrossRef Medline

Sagdullaev BT, Eggers ED, Purgert R, Lukasiewicz PD (2011) Nonlinear interactions between excitatory and inhibitory retinal synapses control visual output. J Neurosci 31:15102-15112. CrossRef Medline

Saszik S, DeVries SH (2012) A mammalian retinal bipolar cell uses both graded changes in membrane voltage and all-or-nothing $\mathrm{Na}+$ spikes to encode light. J Neurosci 32:297-307. CrossRef Medline

Shen Y, Heimel JA, Kamermans M, Peachey NS, Gregg RG, Nawy S (2009) A transient receptor potential-like channel mediates synaptic transmission in rod bipolar cells. J Neurosci 29:6088-6093. CrossRef Medline

Slaughter MM, Miller RF (1981) 2-amino-4-phosphonobutyric acid: a new pharmacological tool for retina research. Science 211:182-185. CrossRef Medline
Sterling P (2013) Some principles of retinal design: the proctor lecture. Invest Ophthalmol Vis Sci 54:2267-2275. CrossRef Medline

Straub C, Hunt DL, Yamasaki M, Kim KS, Watanabe M, Castillo PE, Tomita S (2011) Distinct functions of kainate receptors in the brain are determined by the auxiliary subunit Netol. Nat Neurosci 14:866-873. CrossRef Medline

Tagawa Y, Sawai H, Ueda Y, Tauchi M, Nakanishi S (1999) Immunohistological studies of metabotropic glutamate receptor subtype 6-deficient mice show no abnormality of retinal cell organization and ganglion cell maturation. J Neurosci 19:2568-2579. Medline

Tang M, Pelkey KA, Ng D, Ivakine E, McBain CJ, Salter MW, McInnes RR (2011) Netol is an auxiliary subunit of native synaptic kainate receptors. J Neurosci 31:10009-10018. CrossRef Medline

Tomita S, Castillo PE (2012) Neto1 and Neto2: auxiliary subunits that determine key properties of native kainate receptors. J Physiol 590:22172223. CrossRef Medline

van Wyk M, Wässle H, Taylor WR (2009) Receptive field properties of ONand OFF-ganglion cells in the mouse retina. Vis Neurosci 26:297-308. CrossRef Medline

Vardi N, Duvoisin R, Wu G, Sterling P (2000) Localization of mGluR6 to dendrites of ON bipolar cells in primate retina. J Comp Neurol 423:402412. CrossRef Medline

Vignes M, Collingridge GL (1997) The synaptic activation of kainate receptors. Nature 388:179-182. CrossRef Medline

Wang YV, Weick M, Demb JB (2011) Spectral and temporal sensitivity of cone-mediated responses in mouse retinal ganglion cells. J Neurosci 31: 7670-7681. CrossRef Medline

Wässle H (2004) Parallel processing in the mammalian retina. Nat Rev Neurosci 5:747-757. CrossRef Medline

Wässle H, Puller C, Müller F, Haverkamp S (2009) Cone contacts, mosaics, and territories of bipolar cells in the mouse retina. J Neurosci 29:106-117. CrossRef Medline

Werblin FS (2010) Six different roles for crossover inhibition in the retina: correcting the nonlinearities of synaptic transmission. Vis Neurosci 27: 1-8. CrossRef Medline 